\title{
PENERAPAN METODE PEMBELAJARAN INVESTIGASI KELOMPOK TERHADAP PENINGKATAN PEMBELAJARAN TARI JAPIN KUALA SISWA KELAS X SMA PGRI 3 BANJARMASIN
}

\section{Dewi Rukmini ${ }^{1}$}

\section{Program Studi Pendidikan Seni Tari STKIP PGRI Banjarmasin. iwed.dewigio@gmail.com (0817263446)}

\begin{abstract}
ABSTRAK
Mata pelajaran seni budaya mencakup beberapa unsur seni, diantaranya seni rupa, teater, musik, dan tari. Kendala sering dihadapi guru didalam menyampaikan materi, karena tidak semua guru menguasai keempat bidang seni tersebut sehingga performa guru tidak maksimal dan siswa tidak termotivasi untuk belajar. Pemilihan metode yang tepat dengan melibatkan siswa menjadi salah satu solusi. Berdasarkan hasil observasi di SMA PGRI 3 Banjarmasin, khususnya dalam mengajarkan seni tari, kesulitan yang dialami disebabkan oleh berbagai hal, diantaranya: kurangnya kesiapan belajar siswa, kurangnya disiplin dalam belajar, kurangnya minat dan motivasi dalam belajar, dan kurang efektifnya pembelajaran yang dilaksanakan guru. Tujuan penelitian ini adalah (1) Meningkatkan motivasi siswa dalam pembelajaran seni tari melalui tari Japin Kuala dengan metode investigasi kelompok pada kelas X SMA PGRI 3 Banjarmasin. (2)Meningkatkan hasil belajar siswa dalam pembelajaran seni tari melalui tari Japin Kuala dengan metode investigasi kelompok pada kelas X SMA PGRI 3 Banjarmasin. Jenis penelitian adalah penelitian deskriptif dengan pendekatan kualitatif dan kuantitatif. Penelitian dilakukan menggunakan disain Penelitian Tindakan Kelas (PTK) dengan metode pembelajaran investigasi kelompok. Subjek penelitian siswa kelas X SMA PGRI 3 Banjarmasin, dengan jumlah siswa 30 orang yang terdiri dari 13 orang siswa laki-laki dan 17 orang siswa perempuan. Hasil penelitian menunjukkan bahwa sikap siswa terhadap pembelajaran tari Japin Kuala mengalami peningkatan kearah lebih baik, hal tersebut dapat dilihat dari hasil observasi motivasi siswa yang mengalami peningkatan positif. Hasil belajar siswa dengan metode investigasi kelompok pada siklus I dan siklus II pada pembelajaranTari Japin Kuala terjadi kenaikan dari rata 72 menjadi 87,5, ketuntasan belajar siswa perindividunya mencapai KKM yaitu dengan rata-rata 80 dan ketuntasan klasikal $\geq 80 \%$. Dengan menggunakan metode investigasi kelompok dapat meningkatkan motivasi dan hasil belajar seni tari pada siswa kelas X SMA PGRI 3 Banjarmasin, dengan demikian penelitian ini bisa dinyatakan berhasil.
\end{abstract}

Kata Kunci: Motivasi, Hasil Belajar, Tari Japin Kuala, Investigasi Kelompok

\section{PENDAHULUAN}

Permen diknas nomor 19 tahun 2005 mengatakan bahwa pembelajaran pendidikan diselenggarakan secara interaktif, inspiratif, menyenangkan, menantang, memotivasi peserta didik untuk berpartipasi aktif, serta memberikan ruang yang cukup bagi prakarsa, kreativitas, dan kemadirian sesuai dengan bakat, minat, dan perkembangan fisik, serta psikologis peserta didik. Rendahnya hasil belajar pada satu mata pelajaran tertentu menjadi indikasi bahwa tujuan pembelajaran belum terselenggara secara maksimal. 
Proses dalam bidang psikologis yang mempengaruhi tingkah laku manusia didorong oleh motif-motif tertentu, dan perbuatan belajar akan berhasil apabila didasarkan pada motivasi yang ada pada peserta didik.

Motivasi adalah perubahan energi dalam diri (pribadi) seseorang yang ditandai dengan timbulnya perasaan dalam reaksi untuk mencapai tujuan. Perubahan energi didalam diri manusia, yang akan nampak pada persoalan kejiwaan, efeksi dan emosi yang dapat menentukan tingkah laku siswa.

Motivasi merupakan daya dorong yang memungkinkan peserta didik untuk bertindak atau melakukan sesuatu, motivasi ini hanya muncul manakala peserta didik merasa membutuhkan. Terkait dengan proses pembelajaran, pendidik amat berperan dalam menumbuhkan motivasi belajar peserta didik, dengan jalan menunjukkan pentingnya pengalaman dan materi pembelajaran bagi kehidupan peserta didik dikemudian hari. Sutarjo Adisusilo,J.R (2013: 87)

Mata pelajaran seni dan budaya merupakan pelajaran yang dapat meningkatnya kemampuan untuk mendorong siswa untuk mencapai tujuan belajar yang baru, di dalam mata pelajaran seni budaya tidak hanya belajar kesenian tradisi, seni modern juga diajarkan kepada siswa sesuai dengan konsep pendidikan.

Sebagai seorang pendidik, upaya peningkatan mutu pendidikan merupakan keharusan dan tugas profesi guru. Guru adalah seorang pendidik profesional dengan tugas utama mendidik, mengajar, membimbing, mengarahkan, melatih, menilai dan mengevaluasi para pesrta didik. Pada pembelajaran, guru bertindak sebagai motivator, fasilator, dan koordinator kelas. Untuk itu guru harus berusaha menggunakan stategi, model dan metode yang tepat dalam proses pembelajaran.

Namun dalam kenyataannya tidak semua pelaksaan pembelajaran berhasil sesuai dengan yang diharapkan, yakni: meningkatkan hasil belajar siswa, pembelajaran yang berpihak pada siswa. Tidak memberikan kesempatan pada siswa untuk mencari, membangun pengetahuannya sendiri, pembelajaran yang tidak mengaktifkan siswa dalam kegiatan belajar mengajar (KMB), pembelajaran yang tidak menggunakan media dan metode yang bervariasi merupakan penyebab dari kurangnya maksimalnya hasil belajar yang dicapai oleh siswa.

Berdasarkan hasil observasidi SMA PGRI 3 Banjarmasin, khususnya dalam mengajarkan seni budaya salah satu kesulitan dalam belajar yang dialami disebabkan oleh berbagai hal, diantaranya: kurangnya kesiapan belajar siswa, kurangnya disiplin dalambelajar, kurangnya minat dan motivasi dalam belajar, dan kurang efektifnya pembelajaran yang dilaksanakan guru selama ini. Dari pengamatan peneliti mencari metode dan media yang tepat untuk menarik perhatiandan motivasi siswa, dengan hal ini akan menunjukkan bagaimana hasil yang di dapat akan maksimal. Berdasarkan latar belakang di atas maka dapat dirumuskan permasalahan yang akan diteliti yaitu: Bagaimana proses pembelajaran dan bagaimana hasil belajar siswa kelas X SMA PGRI 3 Banjarmasin dengan metode investigasi kelompok? Dengan asumsi bahwa metode investigasi kelompok siswa akan menjadi termotivasi dalam pembelajaran seni tari karna dapat menumbuhkan sikap kritis dan demokratis pada siswa, melatih siswa untuk dapat bekerja sama, dan melatih siswa untuk saling menghargai. Metode ini juga dapat meningkatkan hasil belajar dan akan menumbuhkan minat dan bakat yang dimiliki siswa siswi kelas X SMA PGRI 3 Banjarmasin 


\section{METODE PENELITIAN}

Penelitian ini dilaksanakan dengan menggunakan disain penelitian tindakan kelas yangmemiliki empat tahap saling terkait dan berkesinambungan yaitu perencanaan, pelaksanaan tindakan, pengamatan dan refleksi.Menurut Arikunto (2009: 74) setiap siklus pada penelitian tindakan kelas terdiri dari tahaptahap, yaitu: (1) Perencanaan (planning), (2) Pelaksanaan Tindakan (acting), (3) Pengamatan (observing), (4) Refleksi (reflecting)

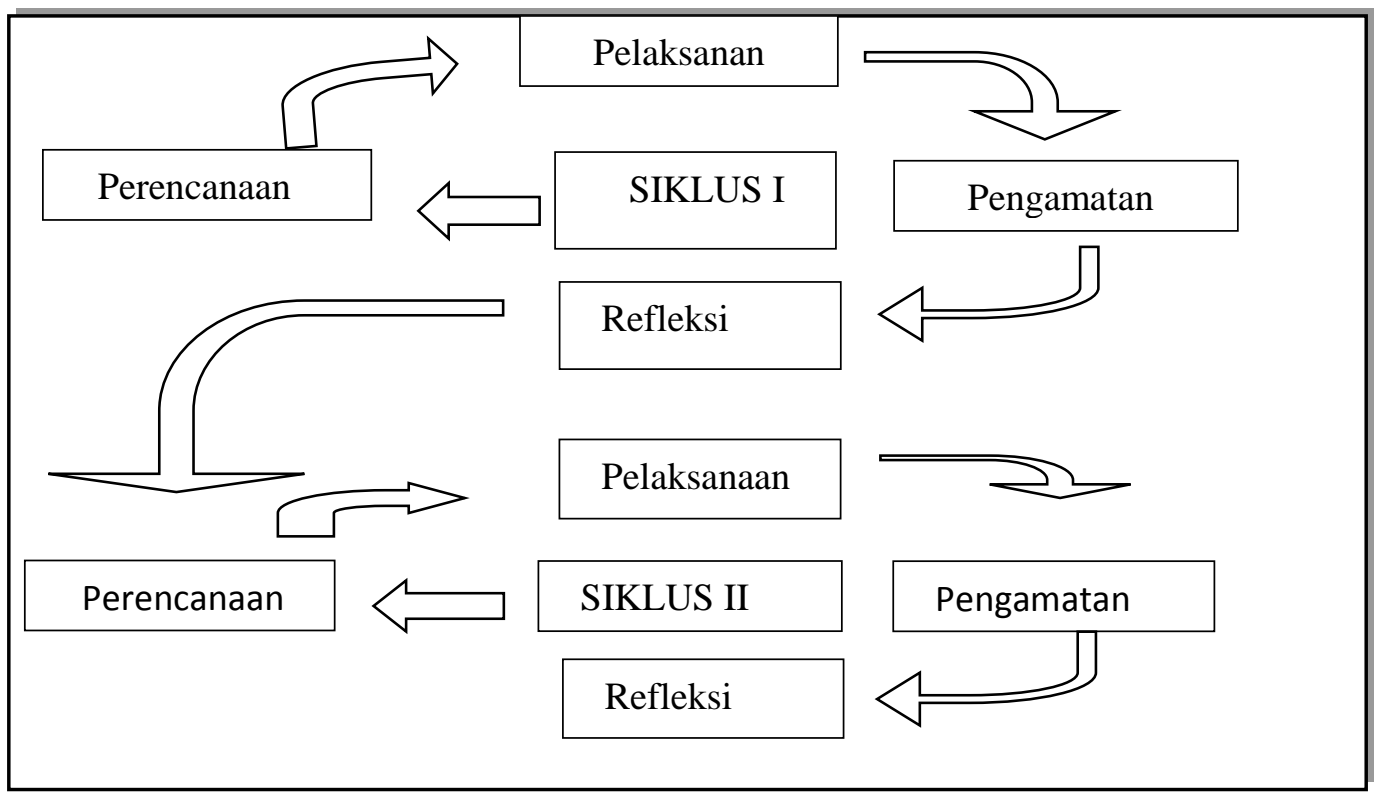

Siklus Penelitian Kelas dari Kemmis dan Taggart

(sumber: asyiknya penelitian ilmiah dan Penelitian Tindakan Kelas , Lusi S Samuel)

Objek dalam penelitian ini yaitu motivasi belajar dan hasil pembelajaran seni tari dengan metode investigasi kelompok di kelas X SMA PGRI 3 Banjarmasin tahun pembelajaran 2016. Peneliti mengambil dengan cara Purposive sampling, yaitu dengan menetapkan sampel yang besarnya ditentukan dan diambil dari seluruh siswa kelas X SMA PGRI 3 Banjarmasin yang berjumlah sebanyak 30 orang siswa/iterdiri dari putra 13 orang dan putri 17 orang.

Rata-rata hitung yang diaplikasikan penelitian pada rentang nilai rata-rata hasil belajar dengan menggunakan rumusan sebagai berikut:

1. Individu : Wiraga+ Wirasa + Wirama

\section{3}

2. Klasikal : $\mathbf{P}=\mathbf{F o} / \mathbf{N} \mathbf{X} \mathbf{1 0 0 \%}$

3. Keterangan:
a. $\mathrm{Fo}=$ Frekuensi observasi yang memilih alternative
b. $\mathrm{N}=$ Jumlah siswa
c. $100=$ Bilangan Tetap
d. $\mathrm{P}=$ Presentase yang dicari 

indikator

Penelitian ini dapat dikatakan berhasil dengan melihat indikator-

a. Indikator Motivasi

Siswa dikatakan termotivasi apabila terjadinya peningkatan keaktifan siswa selama berlangsungnya proses pembelajaran yang ditandai dengan meningkatnya keterlibatan siswa pada proses pembelajaran yang diukur dari lembar angket motivasi yang dibagikan dengan minimal $80 \%$

b. Indikator Hasil belajar

Dalam hasil belajar tergantung dari tercapainya Kriteria Ketuntasan Minimal (KKM) yang berarti bahwa proses penelitian pembelajaran akan dikatakan berhasil jika $80 \%$ dari jumlah siswa dalam satu kelas memperoleh rata-rata nilai $=80$.

c. Indikator Keberhasilan Siswa

Siswa dapat dikatakan berhasil bila terjadi peningkatan pada siklus pembelajaran dan ketuntasan belajar siswa perindividunya tersebut mencapai KKM pendidikan seni, dan ketuntasan klasikal $\geq 80 \%$

\section{HASIL DAN PEMBAHASAN}

A. Hasil

1. Hasil Observasi Aktivitas Guru

Tabel 1. Aktivitas Guru

\begin{tabular}{|c|c|c|c|c|c|c|}
\hline \multirow[t]{2}{*}{ No } & \multirow[t]{2}{*}{ Aspek yang diamati } & \multicolumn{5}{|c|}{ Dilaksanakan } \\
\hline & & $\mathrm{SB}$ & $\mathrm{B}$ & $\mathrm{C}$ & $\mathrm{KB}$ & SKB \\
\hline 1 & Pendahuluan & & & & & \\
\hline & $\begin{array}{l}\text { a. Menyiapkan Rencana Pelaksanaan } \\
\text { Pembelajaran (RPP) }\end{array}$ & & 70 & & & \\
\hline & b. Guru mengecek kehadiran siswa & & 70 & & & \\
\hline & $\begin{array}{l}\text { c. Menyampaikan tujuan pembelajaran yang } \\
\text { hendak dicapai }\end{array}$ & & 65 & & & \\
\hline & $\begin{array}{l}\text { d. Guru mempersiapkan kelas untuk } \\
\text { pembelajaran kelas }\end{array}$ & & 65 & & & \\
\hline & $\begin{array}{l}\text { e. Guru menyampaikan cakupan materi dan } \\
\text { langkah-langkah model pembelajaran } \\
\text { investigasi kelompok }\end{array}$ & & 70 & & & \\
\hline 2 & Kegiatan Inti & & & & & \\
\hline & a. Guru menjelaskan materi yang akan diamati & & 65 & & & \\
\hline & $\begin{array}{l}\text { b. Guru memberikan kesempatan siswa untuk } \\
\text { bertanya tentang materi yang dipelajari }\end{array}$ & & 65 & & & \\
\hline & $\begin{array}{l}\text { c. Guru memotivasi siswa, menarik perhatian } \\
\text { agar mengikuti proses pembelajaran dengan } \\
\text { baik }\end{array}$ & & 70 & & & \\
\hline & $\begin{array}{l}\text { d. Guru menjelaskan materi dengan cara yang } \\
\text { mudah dipahami siswa }\end{array}$ & & 70 & & & \\
\hline & $\begin{array}{l}\text { e. Guru membentuk siswa menjadi beberapa } \\
\text { kelompok yang terdiri dari lima kelompok }\end{array}$ & & 70 & & & \\
\hline & $\begin{array}{l}\text { f. Guru membimbing siswa untuk saling } \\
\text { berdiskusi mengenai pembelajaran }\end{array}$ & & 70 & & & \\
\hline & g. Guru membimbing pembelajaran praktik tari & & 70 & & & \\
\hline & $\begin{array}{l}\text { h. Guru membimbing siswa bekerjasama } \\
\text { dalam kelompok }\end{array}$ & & 70 & & & \\
\hline
\end{tabular}




\begin{tabular}{|l|l|c|c|c|c|c|}
\hline & $\begin{array}{l}\text { i. Guru membimbing siswa bekerjasama antar } \\
\text { kelompok }\end{array}$ & 70 & & & \\
\hline & j. Guru membahas hasil dari diskusi & & 65 & & & \\
\hline $\begin{array}{l}\text { k. Guru meminta siswa agar lebih bersemangat } \\
\text { dalam belajar }\end{array}$ & & 70 & & & \\
\hline $\begin{array}{l}\text { 1. Guru memberikan evaluasi hasil kerja } \\
\text { kelompok }\end{array}$ & & 65 & & & \\
\hline 3 & Kegiatan Akhir & & 70 & & & \\
\hline & a. Guru menyipulkan hasil pembelajaran & 70 & & & \\
\hline & b. Guru mengucapkan salam & & 1300 & & \\
\hline & Jumlah nilai & \multicolumn{3}{|c|}{ Sangat baik } \\
\hline & Jumlah penilain & \multicolumn{3}{|c|}{} \\
\hline
\end{tabular}

Hasil observasi terhadap perbaikan aktivitas guru yang dilakukan oleh observer pada tahap-tahap mengajar melalui metode investigasi kelompok dapat dinyatakan berhasil dan mengalami peningkatan kinerja guru yang membaik. Terlihat dari jumlah skor 13,68 pada siklus II dan pada siklus I sebesar 12,78 terjadinya peningkatan. Hasil tersebut dapat dikategorikan sangat baik dan sudah memenuhi KKM yang telah ditentukan sekolah yaitu 80 .

\section{Motivasi Siswa}

Tabl 2. Motivasi Siswa

\begin{tabular}{|c|c|c|c|c|c|c|c|}
\hline \multirow[b]{2}{*}{ No } & \multirow[b]{2}{*}{ Aspek yang diobservasi } & \multicolumn{5}{|c|}{ Penilaian } & \multirow[b]{2}{*}{$\begin{array}{c}\text { Jumlah } \\
\text { siswa }\end{array}$} \\
\hline & & $\begin{array}{c}5 \\
(\mathrm{SB}) \\
\end{array}$ & $\begin{array}{c}4 \\
\text { (B) }\end{array}$ & $\begin{array}{c}3 \\
(\mathrm{C})\end{array}$ & $\begin{array}{c}2 \\
(\mathrm{~KB})\end{array}$ & $\begin{array}{c}1 \\
(\mathrm{SKB})\end{array}$ & \\
\hline \multirow{6}{*}{1} & Motivasi belajar & & & & & & \\
\hline & a. Tekun & 9 & 7 & 4 & 5 & 5 & 30 \\
\hline & b. Ulet & 8 & 7 & 5 & 5 & 5 & 30 \\
\hline & c. Minat & 8 & 6 & 5 & 5 & 6 & 30 \\
\hline & $\begin{array}{l}\text { d. Berprestasi dalam } \\
\text { belajar }\end{array}$ & 10 & 6 & 4 & 5 & 5 & 30 \\
\hline & e. Mandiri dalam belajar & 8 & 6 & 6 & 5 & 5 & 30 \\
\hline \multirow{3}{*}{2} & Tingkah laku & & & & & & \\
\hline & a. Unsur subjektif & 8 & 7 & 5 & 5 & 5 & 30 \\
\hline & b. Unsur motoris & 10 & 6 & 4 & 5 & 5 & 30 \\
\hline \multirow{4}{*}{3} & Respon belajar & & & & & & \\
\hline & a. Sikap & 10 & 6 & 4 & 4 & 6 & 30 \\
\hline & b. Persepsi & 8 & 6 & 4 & 6 & 6 & 30 \\
\hline & c. Partisipasi & 10 & 6 & 5 & 4 & 5 & 30 \\
\hline \multirow{6}{*}{4} & Keaktifan & & & & & & \\
\hline & a. Kegiatan fisik & 9 & 6 & 5 & 5 & 5 & 30 \\
\hline & b. Kegiatan psikis & 9 & 6 & 5 & 5 & 5 & 30 \\
\hline & Jumlah penilaian & 107 & 75 & 56 & 59 & 63 & 360 \\
\hline & Jumlah skor & 5 & 4 & 3 & 3 & 4 & \\
\hline & Kategori & $\begin{array}{l}\text { Sangat } \\
\text { baik }\end{array}$ & Baik & Cukup & Cukup & Cukup & \\
\hline
\end{tabular}

Hasil observasi motivasi terhadap perbaikan terhadap motivasi siswa yang dilakukan oleh observer pada tahap-tahap mengajar melalui metode investigasi 
kelompok dapat dinyatakan berhasil dan mengalami peningkatan baik dalam pembelajaran siswa.

\section{Sikap Siswa}

Tabel 3. Angket Sikap Siswa

\begin{tabular}{|c|c|c|c|c|c|c|}
\hline \multirow[b]{2}{*}{ No } & \multirow[b]{2}{*}{ Pertanyaan } & \multicolumn{4}{|c|}{ Sikap Siswa } & \multirow[b]{2}{*}{ Jumlah siswa } \\
\hline & & SS & $\mathrm{S}$ & $\mathrm{KS}$ & $\mathrm{TS}$ & \\
\hline 1 & $\begin{array}{l}\text { Saya suka pelajaran seni tari diluar } \\
\text { ruang kelas }\end{array}$ & 10 & 9 & 8 & 3 & 30 \\
\hline 2 & $\begin{array}{l}\text { Saya merasa senang memahami } \\
\text { tentang pelajaran tari Japin Kuala }\end{array}$ & 10 & 9 & 7 & 4 & 30 \\
\hline 3 & $\begin{array}{l}\text { Untuk lebih memahami pelajaran tari } \\
\text { Japin Kuala, saya menyempatkan diri } \\
\text { belajar kembali dirumah }\end{array}$ & 10 & 8 & 7 & 5 & 30 \\
\hline 4 & $\begin{array}{l}\text { Saya sering minta pendapat guru } \\
\text { ketika saya mengalami kesulitan dalam } \\
\text { pelajaran }\end{array}$ & 10 & 7 & 9 & 4 & 30 \\
\hline 5 & $\begin{array}{l}\text { Saya merasa puas, bila saya mampu } \\
\text { mempresentasikan hasil belajar } \\
\text { didepan kelas }\end{array}$ & 10 & 7 & 7 & 6 & 30 \\
\hline & Jumlah total pertanyaan & 50 & 40 & 38 & 22 & 150 \\
\hline & Jumlah Skor & & & & 50 & \\
\hline & Rata-rata & & & & $33 \%$ & \\
\hline & Kategori & & & Sang & berm & \\
\hline
\end{tabular}

berdasarkan angket sikap siswa terhadap pembelajaran seni tari menggunakan tari Japin Kuala dapat dilihat bahwa siswa sudah menyukai pembelajaran seni tari melalui tari Japin Kuala, dan terlihat bahwa frekuensi meningkat dari siklus I

\section{Hasil belajar siswa}

Tabel 4. Rekapitulasi hasil belajar

\begin{tabular}{|c|c|c|c|c|c|c|c|}
\hline \multirow[b]{2}{*}{ No } & \multirow[b]{2}{*}{ Nama siswa } & \multicolumn{3}{|c|}{ Aspek penilaian } & \multirow[b]{2}{*}{ Rata-rata } & \multirow[b]{2}{*}{$\mathrm{T}$} & \multirow[b]{2}{*}{ TT } \\
\hline & & $\begin{array}{c}\text { Kogni } \\
\text { tif }\end{array}$ & Afektif & $\begin{array}{c}\text { Psiko } \\
\text { motorik }\end{array}$ & & & \\
\hline 1 & Abdul Razak & 95 & 60 & 78 & 77,7 & & $\sqrt{ }$ \\
\hline 2 & Ahmad Saufi & 95 & 70 & 77 & 80,3 & $\sqrt{ }$ & \\
\hline 3 & Ahmad Suryani & 90 & 85 & 81 & 81,9 & $\sqrt{ }$ & \\
\hline 4 & Al Arabi & 100 & 100 & 88 & 95,2 & $\sqrt{ }$ & \\
\hline 5 & Alfisah & 95 & 90 & 78 & 86,7 & $\sqrt{ }$ & \\
\hline 6 & Alvin Oktavianus T & 90 & 90 & 77 & 84,8 & $\sqrt{ }$ & \\
\hline 7 & Ananda Putri & 100 & 90 & 81 & 89,4 & $\sqrt{ }$ & \\
\hline 8 & Arman Kusasi & 95 & 70 & 81 & 81,9 & $\sqrt{ }$ & \\
\hline 9 & Azmi Riyadi & 100 & 100 & 88 & 95,2 & $\sqrt{ }$ & \\
\hline 10 & Chandra Yusuf & 100 & 85 & 88 & 87,7 & $\sqrt{ }$ & \\
\hline
\end{tabular}


Penerapan Metode Pembelajaran Investigasi Kelompok terhadap Peningkatan

Pembelajaran Tari Japin Kuala Siswa Kelas X SMA PGRI 3 Banjarmasin

\begin{tabular}{|l|l|c|c|c|c|c|c|}
\hline 11 & Desi Elisa P & 100 & 85 & 88 & 87,7 & $\sqrt{ }$ & \\
\hline 12 & Dilla Aprilyanda & 100 & 90 & 81 & 89,4 & $\sqrt{ }$ & \\
\hline 13 & Hayatun Nisa & 100 & 90 & 88 & 92,2 & $\sqrt{ }$ & \\
\hline 14 & Liana & 100 & 100 & 88 & 95,2 & $\sqrt{ }$ & \\
\hline 15 & Ludia & 95 & 85 & 88 & 86,2 & $\sqrt{ }$ & \\
\hline 16 & M.Andriani Saputra & 100 & 90 & 81 & 89,4 & $\sqrt{ }$ & \\
\hline 17 & M. Untung Supian & 100 & 85 & 78 & 83,7 & $\sqrt{ }$ & \\
\hline 18 & Meisye & 100 & 90 & 88 & 92,2 & $\sqrt{ }$ & \\
\hline 19 & Nor Hayat & 100 & 85 & 81 & 84,9 & $\sqrt{ }$ & \\
\hline 20 & Nor Islamiyah & 100 & 100 & 88 & 95,2 & $\sqrt{ }$ & \\
\hline 21 & Nurul Hasanah & 90 & 85 & 80 & 82,5 & $\sqrt{ }$ & \\
\hline 22 & Resmia Prahesty & 100 & 90 & 80 & 89 & $\sqrt{ }$ & \\
\hline 23 & Rizal & 100 & 90 & 81 & 89,4 & $\sqrt{ }$ & \\
\hline 24 & Saprina & 100 & 100 & 88 & 95,2 & $\sqrt{ }$ & \\
\hline 25 & Taufik & 90 & 85 & 80 & 81,5 & $\sqrt{ }$ & \\
\hline 26 & Yuliana & 100 & 90 & 88 & 92,2 & $\sqrt{ }$ & \\
\hline 27 & Widya Utami & 90 & 90 & 80 & 86 & $\sqrt{ }$ & \\
\hline 28 & Ira Oktaviani & 90 & 70 & 81 & 80,4 & $\sqrt{ }$ & \\
\hline 29 & Rizki Fergiawan & 90 & 60 & 78 & 76,2 & & $\sqrt{ }$ \\
\hline 30 & M. Rafi'i & 90 & 60 & 77 & 75,8 & & $\sqrt{ }$ \\
\hline & Jumlah & 2895 & 2560 & 2479 & 175 & 27 & 3 \\
\hline & Rata-rata & 96,5 & 85,3 & 82,63 & 87,5 & & \\
\hline & Ketuntasan klasikal & $100 \%$ & $80 \%$ & $86,7 \%$ & $98 \%$ & $90 \%$ & $10 \%$ \\
\hline
\end{tabular}

Berdasarkan hasil rekapitulasi test kemampuan siswa dari semua aspek penilaian dapat dilihat adanya peningkatan dari siklus I ke siklus II dengan $90 \%$. Dengan demikian hasil belajar siswa sudah memenuhi indikator keberhasilan.

\section{B. Pembahasan}

\section{Aktivitas Guru}

Berdasarkan hasil observasi terhadap guru pada dua siklus terjadi adanya peningkatan, dari jumlah skor 12,78 pada siklus satu, menjadi 13,68 pada siklus dua, dengan kategori baik. Dari peningkatan tersebut menunjukkan performa guru yang membaik. Peningkatan performa guru terjadi karena guru selalu mempersiapkan materi yang akan dijadikan pertimbangan untuk perbaikan pada proses pembelajaran sebelumnya.

2. Sikap Siswa

Siswa mulai terdorong untuk melakukan proses pembelajaran dengan baik dan dapat diartikan siswa mulai tertarik dengan pembelajaran seni tari dengan metode yang digunan, Siswa yang sebelumnya kurang bergaul terlihat lebih bersosialisasi dengan teman yang lainnya dan merasa bertanggung jawab atas tugas yang mereka kerjakan bersama-sama.

3. Motivasi Siswa 
Peningkatan motivasi yang terjadi dalam dua siklus memperoleh jumlah skor 79 menjadi 107 yaitu sangat baik, dari jumlah skor tersebut siswa sudah mulai terdorong untuk melalukan kegiatan yang berlangsung dan menumbuhkan rasa suka terhadap pembelajaran seni tari melalui tari Japin Kuala.

Hal ini sesuai dengan pendapat Iskandar (2009), motivasi terjadi berkaitan dengan kemaknaan belajar yaitu anak akan tertarik untuk belajar jika yang dipelajarinya sedikitnya sudah bisa diketahui manfaatnya bagi anak dan ketekunan dalam belajar, seseorang yang telah termotivasi untuk belajar sesuatu akan berusaha mempelajari sesuatu dengan baik dan tekun, dan berharap memperoleh hasil yang baik.Hal ini juga berkaitan dengan macammacam motivasi kalau motif yang timbul karena telah dipelajari dan untuk orang lain disekitarnya akan merubah pola tingkah laku seseorang atau yang telah dilakukannya.

4. Akvitas Pembelajaran

Proses interaksi guru dan siswa bertujuan untuk menumbuhkan perkembangan mental sehingga siswa tersebut menjadi mandiri dalam pembelajaran.

Hal ini sesuai pendapat Siti Rahayu Haditono (1989), kemampuan mental semakin meningkat. Hal itu sesuai dengan perkembangan siswa yang beremansipasi dari sehingga ia menjadi utuh dan mandiri.

Aktivitas guru dalam mempersiapkan siswa untuk belajar yaitu menarik perhatian siswa dalam setiap pembelajaran berlangsung dengan begitu siswa mulai terdorong untuk mengikuti pembelajaran dan akan menimbulkan perbuatan siswa yang berubah saat belajar.

Sejak merencanakan kegiatan pembelajaran sudah memikirkan perilakunya terhadap siswa sehingga dapat menarik perhatian dan menimbulkan motivasi siswa. Belajar merupakan proses perubahan tingkah laku secara keseluruhan baik aspek kognitif, afektif, dan psikomotorik perkembangan siswa

5. Hasil Pembelajaran

Berdasarkan hasil penelitian tindakan kelas selama dua siklus terjadi peningkatan terhadap hasil pembelajaran seni tari menggunakan metode investigasi kelompok pada siswa kelas X SMA PGRI 3 Banjarmasin.Dari hasil belajar dapat diuraikan dari dua siklus bahwa pada siklus I nilai rata dari hasil belajar siswa yaitu 69,26 dari nilai 81-100 dengan nilai sedangkan nilai kriteria ketuntasan yang sudah ditentukan yaitu sebesar $80 \%$ dan hasil belajar siswa pada siklus II, ketuntasan siswa dalam mengikuti pembelajaran seni tari dengan nilai rata-rata 88,87 dari nilai 81-100 dengan nilai tersebut hasil belajar siswa pada siklus II sudah melebihi ketuntasan keberhasilan belajar yang ditentukan yaitu $80 \%$.

Meningkatnya hasil pembelajaran disebabkan siswa sudah mampu mengingat dan menggerakkan ragam gerak dari tari Japin Kuala menggunakan metode investigasi kelompok.

Pembelajaran meningkat dengan cara belajar siswa menjadi lebih baik, maupun dalam perilaku sosial dan hasil belajar, Menurut teori Taksonomi Bloom bahwa siswa yang belajar akan memperbaiki kemampuan internalnya, 
dari kemampuan-kemapuan awal pra-belajar, meningkat memperoleh menyusun dan menggunakan pengetahuan, serta kegiatan-kegiatan mental, seperti: mengingat, berpikir, menimbang, mengamati, menganalisis dan mengevaluasi (kognitif), siswa mempelajari kepekaan tentang suatu hal sampai pada penghayatan nilai sehingga menjadi pegangan hidup (afektif), dan belajar berbagai kemampuan gerak dapat dimulai dengan kepekaan memilah-milaih sampai dengan kreativitas pola gerak baru (psikomotorik).

Hasil pembelajaran seni tari yang diambil dari dua siklus mengalami peningkatan yang sangat baik, baik dari segi penilaian individu maupun dalam kelompok. Ini membuktikan bahwa aktivitas yang dilakukan guru selama proses pembelajaran menggunakan metode yang digunakan sangat tepat untuk mendorong siswa agar merasa percaya diri dalam belajar dan membuat siswa bekerjasama dengan siswa yang lain dalam kelompok mereka.

Hasil belajar merupakan hasil dari suatu interaksi tindak belajar mengajar, dari sisi guru tindak diakhiri dengan evaluasi belajar. Hasil dari belajar yang siswa dapat itu meneruskan hasil dampak pengajaran guru yang tepat pada pembelajaran yang telah direncanakan.

\section{PENUTUP}

\section{A. Simpulan}

Penerapan metode investigasi kelompok terbukti telah mampu meningkatkan motivasi siswa dalam proses pembelajaran seni tari di kelas $\mathrm{X}$ SMA PGRI 3 Banjarmasin. Peningkatan motivasi baik berupa hasil motivasi siswa dalam pembelajaran, sikap siswa terhadap pembelajaran seni budaya dengan materi pembelajaran seni tari melalui tari Japin Kuala yang telah mengalami peningkatan serta memenuhi keberhasilan tindakan, sehingga dapat dinyatakan bahwa metode investigasi kelompok dapat di gunakan dan sebagai bahan metode di sekolah pada pembelajaran seni budaya dengan materi pembelajaran seni tari pada kelas X SMA PGRI 3 Banjarmasin terbukti dengan adanya penelitian tindakan kelas yang terdiri dari dua siklus dapat dikatakan berhasil.

Peningkatan hasil belajar siswa dalam pembelajaran seni tari melalui tari Japin Kuala melalui metode investigasi kelompok pada kelas X SMA PGRI 3 Banjarmasin mengalami peningkatan dalam ketuntasan hasil belajar siswa. Peningkatan hasil belajar tersebut dapat dihasilkan karena pembelajaran dengan menggunakan metode investigasi kelompok siswa dapat bekerjasama dan saling membantu antar teman dalam kelompoknya dan membuktikan bahwa setiap orang dalam kelompok untuk mencapai tujuan dan tugas dikerjakan bersama-sama. Dengan begitu dari hasil belajar siswa sudah dinyatakan berhasil dan membuktikan bahwa metode yang di gunakan sangat menunjang kebersamaan siswa yang membuat metode ini berhasil dengan kerjasama siswa dan metode ini sebagai salah satu media untuk membuat siswa untuk terjalinnya kebersamaan dalam kelas.

\section{B. Saran}

Berdasarkan hasil penelitian dan kesimpulan diatas, penelitian mengemukakan Saran-saran sebagai berikut: 
Bagi siswa, dengan metode investigasi kelompok diharapkan dapat dijadikan solusi dalam kendala pembelajaran aktif di sekolah, sehingga motivasi siswa dalam pembelajaran seni budaya termasuk seni tari dapat ditingkatkan.

Bagi guru, dengan metode investigasi kelompok diharapkan sebagai sarana penunjang keberhasilan siswa sehingga siswa dalam pembelajaran semakin aktif dan berupaya mencoba metode yang lain sesuai dengan kebutuhan siswa.

Bagi sekolah, metode investigasi kelompok diharapkan dapat dijadikan sebagai metode alternative pembelajaran yang tepat dan menjadi bahan acuan dalam meningkatkan hasil belajar siswa dalam bidang studi

pembelajaran seni tari di sekolah.

\section{DAFTAR PUSTAKA}

Bakhtiar.S.1990. Pendidikan Seni Tari. Kalimantan Selatan.

Hamalik Oemar, 1992. Proses Belajar Mengajar. Bandung: Penerbit Aksara.

Mudjiono, Dimyati. 2013. Belajar dan Pembelajaran. Jakarta: Penerbit PT Rineka Cipta

Natawijaya, Rahman. 1987. Psikologi Pendidikan. Jakarta: Penerbit CV Prindo Jaya

Nafi.Yulia.2014.Meningkatkan Kebersamaan Dan Minat Siswa Dalam Pembelajaran Seni Tari Melalui Penerapan Metode Investigasi Kelompok Pada Siswa Kelas VIII J SMP Negeri 1 Banjarbaru.Skripsi tidak diterbitkan. Banjarmasin: Program Studi Pendidikan Seni Tari STKIPPGRI Banjarmasin.

Nadia. Firdha. 2016. Meningkatkan Aktivitas dan Hasil Belajar Siswa Pada Pembelajaran Seni Tari Japin Kuala Dengan Menggunakan Metode Peer Lesson Pada siswa Kelas X-2 di SMA Negeri 1 Karang Intan. Skripsi tidak diterbitkan. Banjarmasin: Program Studi Pendidikan Seni Tari STKIPPGRI Banjarmasin

Rohman Noer. 2015. Psikologi Pendidikan. Yogyakarta: Kalimedia.

Sya'dillah, 2005. Motivasi Siswa Sekolah Dasar Negeri Lok Tunggul Untuk Melanjutkan Sekolah di Kecamatan Pengaron Kabupaten Banjar. Skripsi tidak diterbitkan. Banjarmasin: Program Studi Administrasi Pendidikan FKIP Universitas Achmad Yani Banjarmasin.

Sharen, Shlomo dkk. 2006. Group Investigation dan Student Learning. Singapura: Times Grapich

Sidik, Fajar. 2016. Meningkatkan Aktivitas Dan Hasil Belajar Trai Jappin Kuala Dengan Metode Tutor Sebaya Pada Siswa Kelas X MIA 3 MAN 1 
Banjarmasin. Skripsi tidak diterbitkan. Banjarmasin: Program Studi Pendidikan Seni Tari STKIP-PGRI Banjarmasin.

Slavin E. Robert. 2005. Cooperative Learning. London: Allymand Bacon.

Samuel S Lusi dan Ricky Arnold Nggili. 2013.Asyiknya Penelitian ilmiah dan Penelitian Tindakan Kelas. Yogyakarta

Sutarjo Adisusilo, J.R. 2013. Pembelajaran Nilai-Karakter. Jakarta: PT Raja Grafindo Persada

Tim Penyusun. 2017. Pedoman Penulisan Skripsi. Cetakan X. Banjarmasin: STKIP PGRI Banjarmasin

Vernanda, Rizrika, Aditya. 2016. Meningkatkan Aktivitas Dan Hasil Pembelajaran Tari Kuda Gipang Dengan Model Kooperatif Tipe Jigsaw Pada Kelas IX B SMP MUHAMMADIYAH 1 Banjarmasin. Skripsi tidak diterbitkan. Banjarmasin: Program Studi Pendidikan Seni Tari STKIPPGRI Banjarmasin.

W. Gulo . 2002. Strategi Belajar-mengajar . Jakarta: PT Grasindo 